\section{Soviet Environment}

Conservation in the Soviet Union. By Philip R. Pryde. Pp. xv+301. (Cambridge University: London, November 1972.) $£ 5 ; \$ 12.50$.

ENVIRONMENTAL problems are becoming increasingly world wide and in need of a global approach. Little progress can be made to their solution, however, until each particular country has learned to manage its own ecosystem. The many different realms within "Spaceship Earth" differ markedly one from another, not only in physical characteristics and economic structures but, more importantly perhaps, in political ideologies, cultural traditions and in aspirations.

The Soviet Union is one such realm. With more than one-sixth of the Earth's land surface it is deeply concerned with the many problems related to the judicious management of its bountiful, but by no means inexhaustible, biotic and mineral resources. There are instances where damming, diverting, polluting, channelling, draining and other alterations in the aquatic environment have resulted in very adverse effects on important fishing resources. Forest felling has encouraged soil erosion, eliminated wild life habitats, increased stream sediment, damaged fish runs and altered local microclimatic conditions. Surface mining activities have destroyed forests and agricultural lands, induced soil erosion and often seriously polluted nearby streams. Ploughing or grazing on steep slopes, neglect of incipient gullies, improper cropping practices, downslope ploughing, and other poor agricultural practices have contributed to the erosion which now affects two-thirds of the cultivated lands of the USSR.

This study has, as its theme, the contemporary Soviet concern for the conservation of the natural endowments of the country in the face of past and present maltreatment of the environment. Early chapters discuss the historical background of natural resource management in Tsarist Russia and the Soviet Union. The administrative organization governing the use of each broad category of natural resource in the USSR is summarized and some of the major problem areas that have arisen out of the particular Soviet approach are selected for discussion.

Successive chapters deal with land and soil resources, nature reserves, wildlife and fish management, mineral and forestry resources and environmental pollution. The final chapter attempts an evaluation of the contemporary Soviet perception of what constitutes proper natural resource conservation and examines the political and philosophical implications of conservation practice.
One hundred and fifteen of the $\mathbf{3 0 0}$ pages are taken up with an extremely valuable bibliography of Soviet and foreign literature and a large and varied group of appendices covering key terminology, legal documents and resources and environmental data.

Inasmuch as the book represents one of the first broadly inclusive qualitative studies of Soviet conservation practices to be developed outside the USSR, it is to be warmly welcomed. It is unfortunate, though perhaps inevitable, that it should be so expensive.

\section{G. Melvyn Howe}

\section{Exploiting Enzymes}

Enzyme Engineering. Edited by L. B. Wingard, Jr. Pp. xiii +415 . (Wiley: New York and London, October 1972.) $£ 5.20$.

THE thirty reviews, by sixty-one contributors, are based upon two 1971 symposia in the USA. In section 1 the editor defines enzyme engineering as "the sum total of production, isolation, purification, immobilization, and uses of enzymes in a variety of reactor geometries". This section also includes valuable "Recommendations for Standardization of Nomenclature in Enzyme Technology".

The methodology of enzyme overproduction by microorganisms, discussed in section 2, is exemplified by the tonnage of proteases isolated. Cellulase utilization should now be seriously examined at large-scale pilot plant level. Dunnill and Lilly, in section 3, illustrate the future with a description of continuous techniques for disruption and recovery by, for example, multistream continuous chromatography, of several enzymes simultaneously. As one alternative to a mechanical technique they disrupt bacteria using lysozyme immobilized on soluble dextran (molecular weight $2 \times$ $\left.10^{6}\right)$, followed by ultrafiltration. No doubt other uses of soluble immobilized enzymes will follow. For enzyme separations, Porath mentions a new range of amphoteric ion exchangers and evaluates affinity chromatography.

The section on enzyme immobilization omits recent simplified techniques. Attainment of stability may require chemical modification of enzyme prior to immobilization, although Zaborsky disappoints us by providing no details of his own work to which he alludes. Section 5 covers kinetics and performance of enzyme reactors. Apparently, 500 columns, each of $1 \mathrm{ft}^{3}$ volume of immobilized glucamylase, would replace the total present enzyme production of glucose syrups from corn starch in the USA; but the economics of the process are questionable. On the other hand,
Ford et al. describe a $10-\mathrm{ml}$. capacity recirculation reactor useful for immobilized enzyme kinetics studies.

The book also includes analytical techniques using enzyme electrodes and the potential for microencapsulated enzymes in therapy, and is an invaluable collection of data and ideas in spite of the regrettable absence of widespread commercial utilization of immobilized enzymes to date. The one such application, racemase in Japan, is, however, quoted repeatedly. Where is the profitable return for so much "biochemical ecstasy"? No one is prepared to divulge this yet. Is reactor operation in fact proving too expensive for some? In addition, natural enzymes, or multienzyme systems, may be superseded by synthetic ones sooner than many think (the "time bomb hanging over enzyme engineering"). Nevertheless, the future will be exciting if industry can be induced to make it so. The next symposium in summer 1973 should be fascinating!

This book is good value for money, but its author index is irrelevant and the subject index is almost useless due to its extreme brevity.

\section{B. J. Gould}

A. WrSEman

\section{Shaping of Plants}

Patterns in Plant Development. By Taylor A. Steeves and Ian M. Sussex. Pp. xvii + 302. (Prentice Hall: Englewood Cliffs, New Jersey, October 1972.) $\$ 10.95$.

THE dust cover announces that this book presents a factual account of the phenomena of development in the vascular plants. The book is not, however, a dry documentation of anatomical events from zygote to adult. Instead it outlines the variations in structure that are encountered from Bryophytes to Angiosperms and presents experimental evidence for how environmental and endogenous chemical and physiological factors are believed to modify the pattern of development. Each of the seventeen chapters surveys a particular aspect of development, setting out the problems for the reader and pointing to areas of understanding which can profitably be expanded by future work. Each chapter concludes with a section of general comment and up to thirtytwo selected references.

The essential plasticity of leaf form and regulation of shoot growth in relation to hormones from leaves and stem are nicely presented. The conversion of vegetative to reproductive apices is related to the change from indeterminate to determinate growth and is linked to biochemical activities of the meristem itself. The similarities and differences 